\title{
LA MUERTE: EXPERIENCIAS DE AULA
}

\section{L} a muerte suele ser uno de esos temas de los que se trata de huir, no queremos abordarlo. Quince milenios de transitar, el ser humano por el Universo y, la muerte sigue siendo extraña y misteriosa.

Las alumnas y alumnos de "Cuidados Paliativos" abordan el tema de manera natural y profesional, enriquecedora para ellos y de gran ayuda para aquellos a quienes dirigen sus Cuidados.

En el aula, con trabajos muy pequeños, casi de niños, tratan de acercarse a ella. Los años, la experiencia o los muchos títulos, sirven de muy poco. De puntillas y atisbando podemos experimentar sensaciones de momentos dolorosos.

Como trabajo de reflexión y acercamiento a la muerte, han escrito una carta de despedida a un ser querido, espontánea y con el corazón en la mano.

Presentamos algunas de estas cartas para que a otras personas les ayude a pensar en una muerte; a la que todos estrecharemos la mano, como en un saludo de bienvenida, en un tiempo no muy lejano.

Algunas cartas aparecen con el nombre de su autora o autor; otras, han preferido el anonimato.

Gracias a estas alumnas y alumnos por la experiencia vivida, llena de emoción y sinceridad. Son pequeños detalles que realzan nuestras vidas cotidianas y nos hablan del valor de la persona. El valor de lo pequeño nos engrandece.

\section{CARTA DE BELÉN A SU MADRE}

\section{3 de Febrero del año 2.001}

Siendo consciente del estado en que me encuentro y del poco tiempo que me queda por delante, me dirijo a ti mamá para despedirme. Jamás pensé, o quizás alguna que otra vez, mi interés por el tema, que ésto sucediera tan pronto. En ésta ocasión me ha tocado a mí y sé lo doloroso que todo esto es para ti. Me preocupa mucho cómo te sientas cuando yo ya no esté aquí, pero me gustaría que te acordaras, de aquellos momentos, en los que por estudios o por trabajo, ambas, hemos permanecido separadas durante largo tiempo. Piensa que yo estoy de viaje (algo que tanto te gusta y que espero que sigas haciendo tras mi mar- cha), que estoy en un lugar estupendo del que no quiero regresar y que por ello no vuelvo, y que cuando llegue el momento tu visitarás.

Quiero que sepas lo importante que has sido para mí, mi apoyo fundamental, y que como madre, has sido la mejor.

Aprende a vivir sin mí, pero sabiendo que siempre estaré junto a ti.

\section{Belén Juan Carrión}

\section{CARTA DE ANA GARCÍA LLORET}

Soy una enferma terminal y sé que voy a morir.

Te preguntas como lo sé, si me lo han dicho. La verdad es que no hace falta hablar, lo veo en la cara de la gente; de mi familia, amigos, de la enfermera que viene a casa cada tres días.

Yo también soy enfermera y quizás ello me ayude a saberlo.

Estoy viviendo los últimos días en casa; mi madre es la que se encarga de mí siempre, ella es la que me arregla y me tiene impecable, me lava todos los días y el día que tiene más prisa, lo noto por la manera de manipularme.

Lo que más me duele es la duda de lo que vendrá después de morir, quiero hablar con alguien, el problema es que ¡No sé con quien!

Marta, mi enfermera, viene a casa dos veces por semana y me mira si se me ha hecho alguna úlcera, o si tengo dolor, pero nunca hablamos de mi curación y del mañana.

Todo ello me ha inducido a inventar una cosita, como ya no tengo fuerzas para escribir, le digo a mi madre que deje la grabadora encendida y, hablo largas horas sola, me hago preguntas sin contestación y así procuro expresar todo lo que tengo ganas de decir.

Lo que más agradezco es cuando viene mi padre de trabajar y me habla de lo que haremos el verano que viene, donde iremos. Yo me imagino que es verdad y sueño, a veces me enfado al oírlo y me dan ganas de decirle que no me mienta; que sé la verdad, que no estaré, pero callo, siempre callo.

Sé que la muerte está cerca, casi la puedo palpar y en estos momentos me gustaría hablar de cómo me 
gustaría que fuera el fin, el inconveniente es que a mí alrededor el tema incomoda, por ello callo y cuando me preguntan siempre digo ¡Parece que este tema incomoda, por ello callo, callo y cuando me preguntan siempre digo ¡Parece que esté mejor!

\section{CARTA DE DESPEDIDA}

Querido José:

Recuerdas que te decía: "¿Vas a estar siempre conmigo?", y tú contestabas: "Siempre que tú quieras", "entonces sí", replicaba yo. Pues bien, alguien ha querido que yo sea la traidora, y ahora te dejo yo aquí.

Sabes lo difícil que es este momento para mí, y para ti y los demás también. Yo amaba la vida y siempre me he revelado contra este momento, y lo seguiré haciendo con las fuerzas que me quedan. Pero tengo mucho miedo, siento una gran angustia e incertidumbre sobre lo que va a pasar conmigo, pero una vez más tú has unido tus fuerzas a las mías para luchar.
Sabes que eres lo más bonito que he tenido en mi vida y me has dado mucha ilusión. Me has ayudado a subir cuando me derrumbaba, y a mantenerme cuando hacía un amago. Te quiero con locura y no he dejado de hacerlo durante los cinco años y medio que te conozco. Sé que he tenido una suerte inmensa porque como tú hay pocos, y me llevo algo muy bonito conmigo. Te echaré mucho de menos, porque ya sabes, que no puedo estar mucho tiempo sin verte, pero me voy, con la satisfacción de haber compartido contigo este amor.

Para despedirme, sólo decirte que sigas siendo así, para gozo tuyo y de los que están a tu alrededor, y desearte que si alguna vez encuentras otra chica, que sepa quererte y valorarte, y te haga feliz.

Yo siempre estaré contigo.

Te quiero. Tu novia,

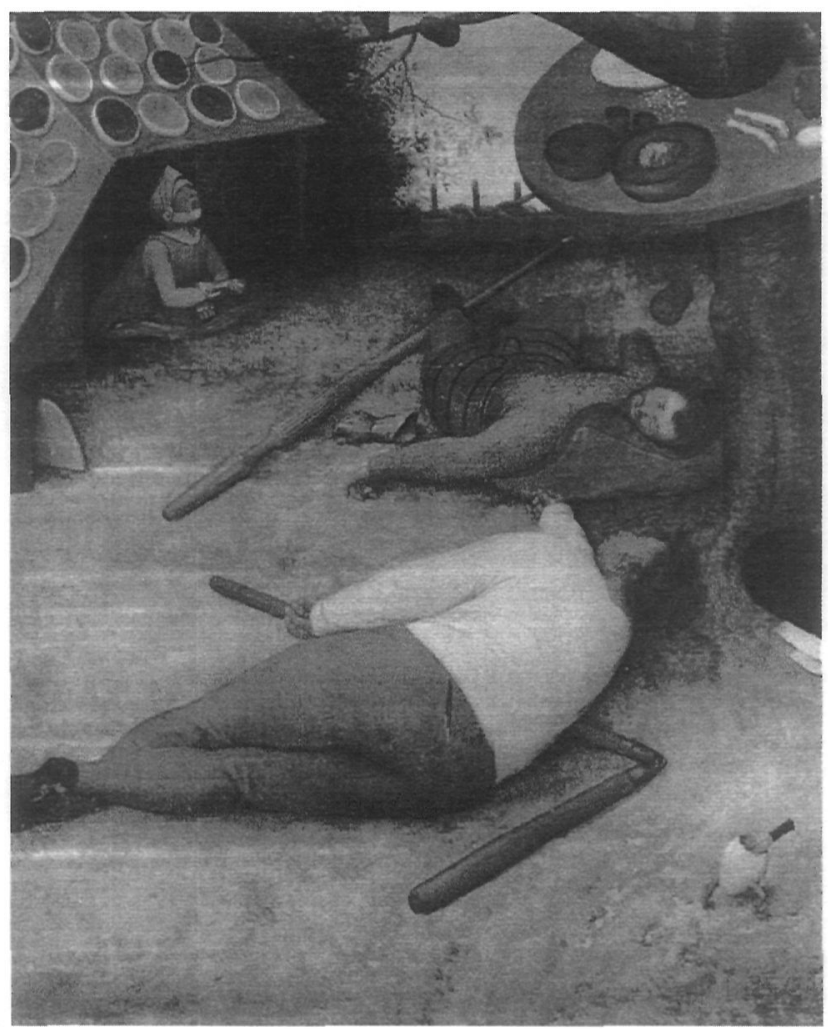

